\title{
BANDUNG JENGKI FROM HERITAGE POINT OF VIEW: DOCUMENTATION AND PRELIMINARY SEARCH ON SIGNIFICANCE
}

\author{
WULANDARI, Ratri \\ Interior Design Programme, Telkom University \\ Jl. Telkomunikasi No. 1, Terusan Buah Batu, Bandung - INDONESIA \\ Email: ratriwulandari@tcis.telkomuniversity.ac.id
}

\begin{abstract}
Jengki architecture is one of Indonesian post-colonial architecture style popular in 1950 to 1970. Most study of Jengki was done in Jakarta, Semarang, and Malang. In Bandung, there is no written record of Jengki identification or documentation found. This paper tries to recognize and document Jengki typology in Bandung as a preliminary study on its presences, and its variant, in the city. It also tries to look at this typology from heritage point of view, whether there is significance in accordance to heritage criteria. Using site survey and Google street view, data were collected and elaborated in table to recognize Jengki traits in a suspected building. Building's significances were then reviewed using criteria mentioned in local legislation. It is found that not all suspected Jengki building contain all Jengki traits rather more late modern Indonesian character. Private buildings were assessed to have less heritage value, while public building retains more. Deeper study and documentation on Jengki in Bandung are still needed to legitimate Jengki as heritage since there is no study ever done previously on this issue.
\end{abstract}

Keywords: Jengki architecture; Bandung.

\section{INTRODUCTION}

Jengki architecture is an architectural style that developed in Indonesia and spread all over the country in the decade of 50's and 60's. (Prijotomo, 1996; Roesmanto, 2004; Sukada, 2004 in Widayat, 2006) and its existence is in threat since more and more "old" building are being sold and change face into other function and form. The Jengki becomes rare every single day.

This particular architecture style has been an object of study for the last 25 years as it marked an important architectural style period in Indonesia's modern architecture of post-independence era. Scholars have argued of its origin and made theories of its characteristics. The first recorded writing about Jengki is of Josef Prijotomo on Surabaya Post in 1992. Since then, more scholars were getting interested in Jengki. Prijotomo, Roesmanto, Silas, Sukada, Prakoso, Kurniawan, Widayat, Setyabudi et al, Susilo, are some names who have studied Jengki, mostly taking local examples of existing Jengki building in their respective cities. The city that has been used as Jengki study case so far is Malang, Surabaya, and Semarang. Most of theories which are used up to present came from Prijotomo, Roesmanto, Silas, and Sukada.

Latest study and documentation was done by Tariq Khalil, a photographer with passion on building, since 2009. His work on Jengki has presented as a book titled "Retronesia: Indonesia's High Style Rediscovered" published last year (2015). Retronesia is a book containing photographs collection of Jengki Building all over Indonesia with little description or story of it. Retronesia is the most elaborated work of jengki so far in which author took a little part in its research process in 2011.

This paper aims to identify Jengki building in Bandung through their visual characteristic as recognized by mentioned scholars to add more documentation of this style, in Bandung in particular. It is also meant as a preliminary assessment on significance of Jengki building from heritage point of view as a specific architectural movement from 1950's. Further it may serve as one reference of Jengki in West Java in general and in Bandung in particular.

\section{JENGKI ARCHITECTURE: ORIGIN, CHARACTERISTICS AND DEVELOPMENT}

\section{Origin}

The term Jengki architecture was popularized in 1990's through writing of Josef Prijotomo in Surabaya Post in 1992 (Kurniawan, 1999). The word Jengki itself suggested to be inspired by the word yankee of the American armed force (Prijotomo, 1996). While Sukada (1996) in Kurniawan (1999) said that Yankee was a product of American pop culture such as pants, bikes, etc. 
Johan Silas, in Prijotomo (1996), said that Jengki style is an expression of freedom translated into architectural form differs from previous style introduced by the Dutch, part of expression of the political spirit of freedom (from colonization) in Indonesia. The Jengki appearance happened also due to lack of architect during the transition period when most Dutch architects were sent back home and new local architects emerged (Sukada, 2004; Prakoso, 2002 in Widayat 2006). Silas (2003) in Widayat (2006) mentioned that the oblique façade of Jengki was inspired by American cowboy movie scene where the cowboy set a position to draw his gun in fight. Further in analysis of Jengki aesthethic value, Widayat (2006) proposed that the pentagon shape of Jengki houses was inspired by the country symbol of Indonesia, Pancasila. He mentioned that this speculation came from situational analysis of Indonesia when the spirit of nationalism was strongly presented in the Indonesian life. Thus the visual form of Pancasila was translated into pentagon form and presented in architecture, as well as logo or symbol of institution, with a number of variation.

Handinoto dan Samuel Hartono (2006) said that changes of form and style in architecture is often preceded by social changes in the society. Sigfried Gideon (1971:4) in Handinoto. Samuel Hartono (2006) stated that the backgrounds of changes in architectural forms are religion and social changes, as well as new invention and new technique development. New aesthetic movement could be born as a form of resistance to its earlier movement favored by technological advancement, for example the birth of the modern to counter the neo classical, the birth of post modern to counter the modern. It could be a resistance born out of disappointment and rebellion to the previous style, as is Jengki predicted by many of the above scholars. It could also be a form of imitation (or a nostalgic) to historic style reference in simpler or more free expression, all favored by technological advancement. The example is the shift from classical Greece to classical Rome. Or it could be born simply out of needs as the case of many constructions in the world, for example the shift from Romanesque to Gothic. Widayat (2006) stated that all premises on origin of Jengki forms are still arguable and need further research.

\section{Characteristic and Development}

Prijotomo (1996) stated that the characteristic of Jengki is transformation of modern cubic and strict geometry into more complicated form of pentagon or other irregular solids. Other characteristic mentioned by Prijotomo (1996) are pitched roof and festive composition and surface. These characteristics were described more detail by Kurniawan (1999) as follows:

1. Pitched roof with 35 degree of slope. In later development, according to Sukada, the pitch didn't meet in the center rather composition with different height, constructing 2 shape of triangle of the facade. One of the triangles was then shifted so the triangles of the pitch roof are in different height and depth.

2. Oblique gavel, mostly in pentagon shape, as an expression of anti-straight line. Positioning of gavel divers according to design. On other type, this oblique form took shape on column which has small size at the bottom and bigger on top.

3. Rooster or vent hole, an important element forming the façade of Jengki houses that adapt various shapes such as diamond, circle, irregular trapezium, rhombus, polygon.

4. Terraces as a balancing element of the whole composition.

5. Concrete frame and other ornamental element. Types of ornament has linear line pattern combined with curved lines, examples can found in Surabaya.

Widayat (2006), Susilo (2009) and Setyabudi et al (2011) followed these criteria as characteristic of Jengki. Setyabudi et al (2011) however added two other descriptions didn't mentioned by Kurniawan. They are:

1. Basic spatial form of cube disregarding its oblique exterior form

2. Combination of wall covering material comprise of split stone slab, serit masonry, cubical sandstone, egg stone layer.

Widayat (2006) resumed Roesmanto, Prakoso, and Sukada, described few other characteristic of Jengki building as follow:

1. Slopping exterior wall forming a pentagon.

2. Flat roof on terraces supported by a "V" shape iron poles.

3. Asymetrix window sills and door frames to express new kind of aesthetic.

He also argued that Jengki houses are usually presented in dense area as settlement and around suburbs as villas. That Jengki houses are so far understood as single unit and seldom found row Jengki in a neighborhood, rather scattered.

Further, Sukada in Kurniawan (1999) recognized two patterns of Jengki. The first is early pattern 
with pentagon form on a box in a critical extreme position (for a multi-storey building) or pentagon on the ground for a single storey building. The second is new pattern which took form of popular American housing, though is not very clear of which American housing.

Roesmanto (2007) stated that Jengki developed to simpler façade by 1970's. The sticking out Jengki roof changed into complete pitched, but window sills remained Jengki. That those walls were no longer sloping but varieties vent holes persisted. Front wall were shifted to put front door and presence of luifel (flat or folded plate) to cover terraces. He also said that by 2000's it exist the Neo Jengki or Jengki Revival style with focus of Jengki on window sills seam and pillars.

Later, Susilo (2009) reviewed the geometry of Jengki from aesthetic point of view taking examples of few buildings. He examined how every element of the façade connects each other. He argued that the way the architect treated the building functionally had given it an aesthetic value. Also he stated that Jengki presence had given surprise in Indonesia for its contrasting appearance compared to modern architecture that existed. This contrast, he analogue, is like a tacky girl between simple elegant girls because of its daring ornamentation. He said that the Jengki forgot an important element in Indonesian architecture design: climate, that it contained too much drain pipe that gave difficulties in its maintenance.

More about the contrasting style of Jengki vice versa the modern, Widayat (2006) stated the differences between colonial architecture and Jengki are very clear. He stated that the colonial architecture is classic oriented with strong characteristic on cripedoma (stairs to building), classical columns, pediment, tympanum, and classical ornaments. On the other hand, the Jengki are less ornamented. The last is very much contradictory to Susilo who stated clearly that Jengki has daring ornamentation, which is quite the case in many early Jengki found all over Indonesia.

On the development of Jengki, Setyabudi et al (2011) said that according to a Malang historian, the Jengki in Malang were built by the wealthy at the beginning in a wild pattern. By 1965's it was started to be built by other economic class in smaller size (new pattern). It continued in 1970's in the suburb and villages.

It can be concluded that the characteristic of Jengki differs according to its development from its early birth to newer simple version with dominant physical elements consists of but not all:
1. pentagon shape whether constructed by linear or sloping wall;

2. complete or shifted pitch roof;

3. oblique gavel;

4. varieties vent holes;

5. concrete frames;

6. terraces;

7. flat or folded roof (luifel) covering terraces;

8. "V" shape pole;

9. asymmetric window sills;

10. Oblique pillar with smaller bottom than top.

Either the building possesses a number or all of the above elements, it can be predicted that the building is of Jengki style whether early type or later, depends on the year of construction

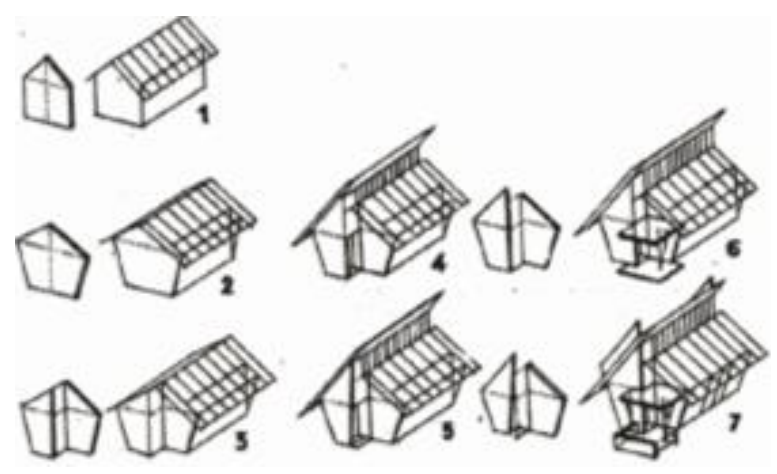

Figure 1. Sketch on Jengki development from Kampong house, 2004 (Source: Roesmanto - Suara Merdeka).

\section{HERITAGE IN BANDUNG AND JENGKI}

In 2009 Bandung government formulated law to protect the city's tangible and intangible heritage property. The law was publish as Perda (local legislation) No. 19/2009 on Pengelolaan Bangunan dan Kawasan Cagar Budaya Kota Bandung (Management of Heritage Building and District) and Perwal (mayor regulation) No. 921/2010 on Pedoman Pengelolaan Kawasan dan Bangunan Cagar Budaya Kota Bandung (guideline on Management of Bandung Heritage Building and District). These laws were published before the birth of national law No. 11 /2010 on Cultural Heritage which made Bandung law doesn't sync very well with the national law and therefore need some revision.

Bandung local law on heritage protection is a starting point in valuing the city's heritage property although it's focused on built architectural heritage with only 100 building acknowledged having heritage values and needing protection. The 100 buildings come mostly from architecture from the colonial era. The Law No. 19/2009 mentioned several criteria for a 
building to be valued as heritage property. The criteria are:

a. historical value

b. architectural value

c. scientific value

d. social and cultural value

e. Age, at least 50 years of age according to Law no. $5 / 1992$ on heritage objects.

Accordingly, Bandung built heritage property is classified in 3 classifications:

a. Class A (Utama), meeting at least 4 criteria;

b. Class B (Madya), meeting at least 3 criteria;

c. Class C (Pratama), meeting at least 2 criteria.

Since one of heritage criterion is age of 50 years, a question is raised of whether Jengki can be considered as cultural heritage? To answer the question, a heritage assessment needs to be done on Jengki architecture in general, in accordance to criteria mentioned by the law. In further research, an assessment of significances needs to be done to each individual building to acquire its values from heritage point of view and to decide whether it is to conserve as heritage property or not.

The Jengki and late Indonesian modern architecture which were built in 1950's and 1960's (maximum 1965) have met age criteria mentioned in Law no. 5/1992 and therefore, in theory, it deserves treatment as cultural heritage property and then conserved. Further, the architectural style has met also criteria b which is architectural value as a style developed in a specific era, in this case the 1950-1960 eras. Jengki has also met criteria $\mathrm{c}$ which is scientific value, in this case as an important step in architectural movement in Indonesia after war. As for criteria a, each property needs to be studied individually, as well as criteria $\mathrm{d}$, considering that most of Jengki architecture are in private ownership.

\section{METHODOLOGY}

The research is using qualitative analytic-descriptive research. It was done through a preliminary survey of some Jengki architecture around Bandung and literature comparative study. On survey, buildings were photographed, and when possible, owners were interviewed. History of the building was explored through interview to recognize its early function, changes, renovation, and ownership. Private houses didn't allow interior photograph due to privacy concern so did several public building. The building was recognized by characteristics mentioned earlier and listed in table. Some other building was searched via Google street view as early recognition of Jengki building and its location.

An early assessment of significance were then elaborated using criteria mentioned in local legislation by giving a positive mark (+) when a criterion appears, negative mark (-) when a criterion absents, and a question mark (?) when it is unknown or no information was obtained. The more a building has positive value, the more it is considered eligible to be acknowledged as heritage property.

Difficulties were met on search of historical and social-cultural significance of each building which need further research through anthropological approach. Only partial information could be gathered in this research. The information is presented in the table along with the visual documentation of the building.

\section{RESULTS AND DISCUSSION}

Bandung is actually a city quite rich with Jengki building scattered all over the city. Most private housing with Jengki style was detected around Buah Batu, Pajajaran area, and at the periphery of the city. Other Jengki building took form of public building, secular and religious, single story to multistory, with various type of physical characteristics

In 2011, author was asked to do survey of Jengki in Bandung by Tariq Khalil, author of "Retronesia". At time Khalil recognized several public buildings in Bandung as Jengki architecture. They are Parahyangan University Post Graduate Building in jalan Merdeka, Bumi Sangkuriang in Ciumbuleuit, Regional Water Company housing complex in Tamansari, Poltekkes, and Balai Pertemuan Ilmiah ITB. Khalil only recognized one private house in Bandung though his other examples from other city were mostly private housing.

In Table 1, elaboration of eleven recognized Jengki buildings are presented, along with information obtained on their history and social-cultural role. As history of each building is difficult to collect, only few with very limited information obtained are presented for instance. The exterior physical characteristics of suggested Jengki found are reviewed to recognize the building typology.

Parahyangan University building suggested to be Jengki by Khalil showed character closer to late modern Indonesian with characteristic features (according to Prijotomo, 1996) consist of folded flat roof and the use of brisse soleil. The signifance of the building in heritage point of view is still questionable due to lack of social-cultural-historical information gained in the first survey. 
Tabel 1. Elaboration of Jengki building in Bandung, May 2016

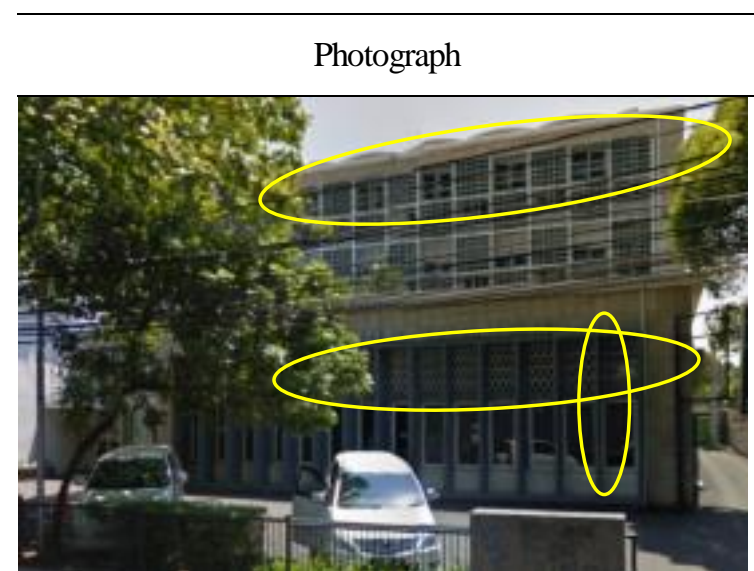

Figure 2. Parahyangan University - Post graduate building, 2014 (Source: Google Street View).

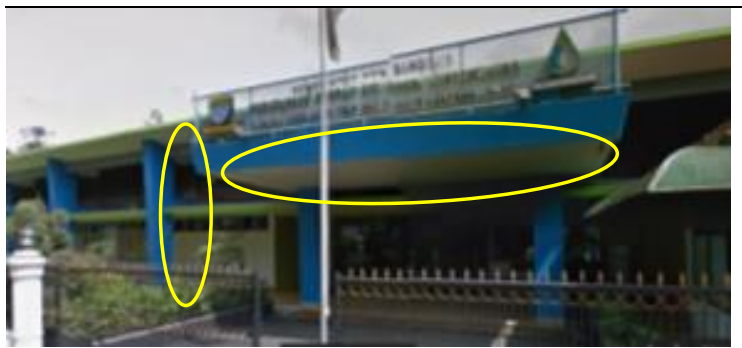

Figure 3. Drinking Water State Company, 2014 (Source: Google Street View).

$\begin{aligned} & \text { Exterior Physical } \\ & \text { Characteristics }\end{aligned}$
Folded roof;
attractive vent
holes; concrete
frame; brise soleil.
Showing a
character more of
late modern
Indonesian
architecture than
Jengki.
historical information Belong to Parahyangan University, functioned as post graduate building. No history obtained for instance. (+) a good example of late modern Indonesian style

- scientific value: (?) no information obtained.

- social and cultural value: (?) no information obtained.

- Age: (+) $\begin{array}{lll}\text { Flat roof on } & \text { The first drinking } & \bullet \text { historical value: }(+) \\ \text { terrace; oblique } & \text { water filtration center } & \begin{array}{l}\text { as the first water } \\ \text { pillars. }\end{array} \\ & \text { in Bandung and still } & \text { filtration center in } \\ & \text { operating. Bandung } & \text { Bandung. }\end{array}$

The only character of had water springs in Ledeng area which is Jengki is oblique distributed all over pillar and flat roof the city. After war, on terrace. the water company saw the necessity in finding other clean water system, thus this water filtration center was built. It was built with the French government aid along with housing complex nearby to facilitate the French engineers working on the project. The housing complex was also built in Jengki style.

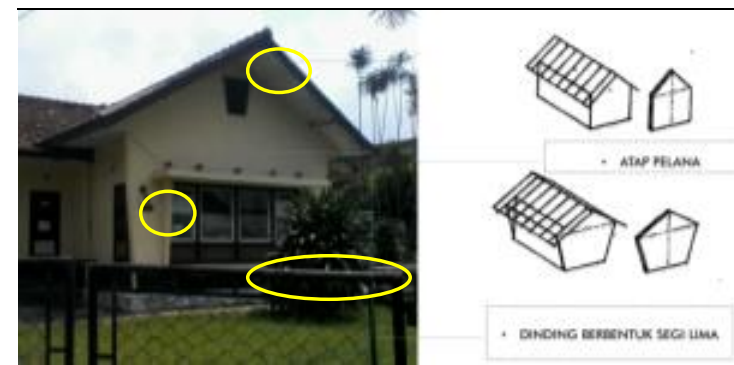
Pentagon shape Housing estate near bended sidewall; military cluster, variety vent holes; occupied by military concrete frame officers.
- architectural value:

(+) contain characteristic of Jengki though the building is less maintained.

- scientific value: (+) Architecturally as an example of Jengki and technically contains water filtration technology from 1960's

- social and cultural value: (+) as the first water filtration center in Bandung.

- Age: (+) age reaching 50 years.

- historical value: (?)

- architectural value:

(+) an example of early Jengki in Bandung.

- scientific value: (?)

- social and cultural value: (?)

- Age: (+)

Figure 4. Private house at Katamso street, 2013

(Source: UNIKOM Architecture student survey). 


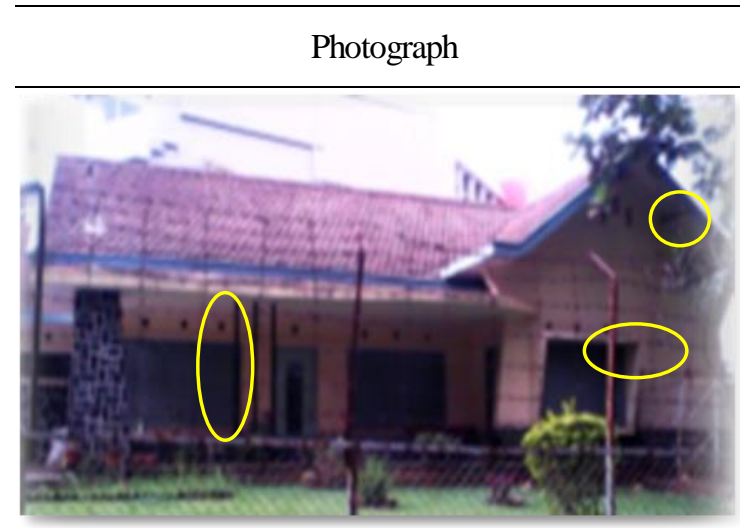

Figure 5. Private house at Teuku Umar street, 2013 (Source: UNIKOM Architecture student survey).
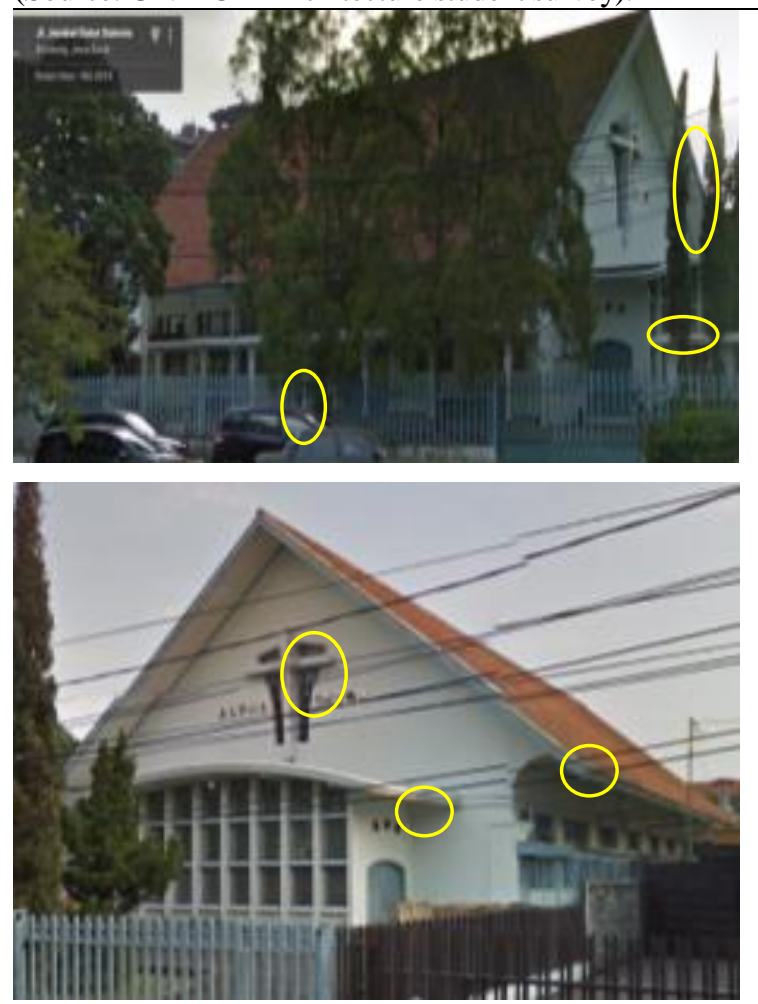

Figure 6. Alpha Omega Church, Gatot Subroto street, 2014 (Source: Google Street View).

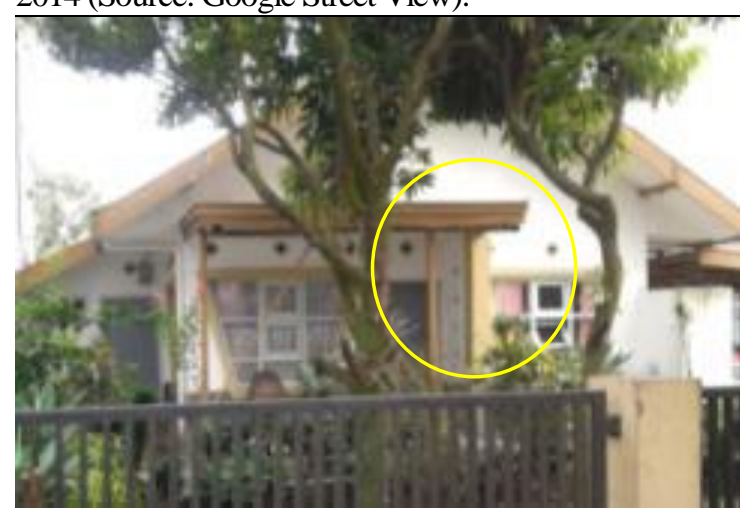

Irregular concrete A private house near frame; varieties vent holes; the city periphery with varieties straight wall; flat characteristic of roof on terrace but Jengki. No specific without "V" iron pole information obtained for instance.
- historical value: (?)

- architectural value: (+) an example of religious building in Jengki style.

- scientific value: (?)

- social and cultural value: (+) one religious building, a Pentecostal church in Jengki style.

- Age: (+)

Figure 7. Private house at Abdurrahman Saleh street, 2016 (Source: author). 


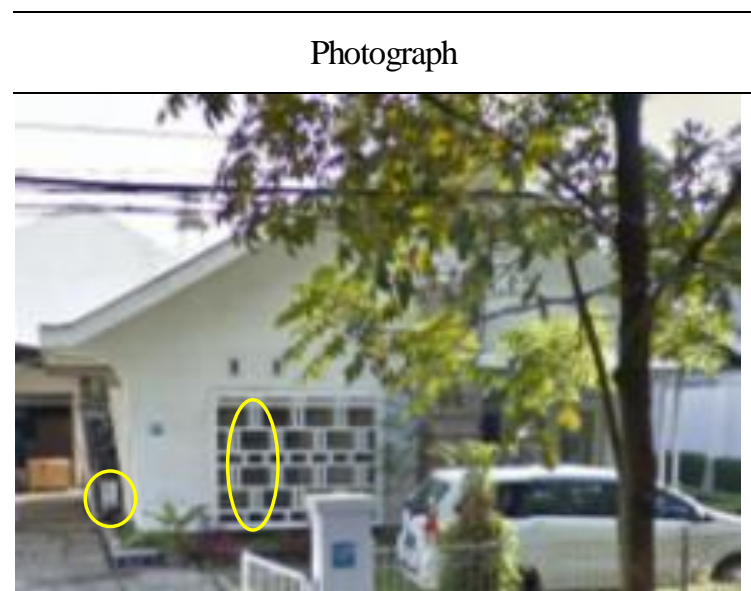

\begin{tabular}{clc}
$\begin{array}{c}\text { Exterior Physical } \\
\text { Characteristics }\end{array}$ & $\begin{array}{c}\text { Social-cultural- } \\
\text { historical information }\end{array}$ & $\begin{array}{c}\text { Assessment on } \\
\text { heritage criteria }\end{array}$ \\
\hline Concrete frame; & Example of another & $\bullet$ historical value: (?) \\
bended sidewall; & variant of Jengki & $\bullet$ architectural value: \\
V shape iron pole & house. No specific & $(+)$ an example of \\
& information obtained & Jengki variant in its \\
& for instance. & development.
\end{tabular}

- scientific value: (?)

- social and cultural value: (?)

- Age: (?)

Figure 8. Private house at Sampurna street, 2014 (Source: Google Street View).

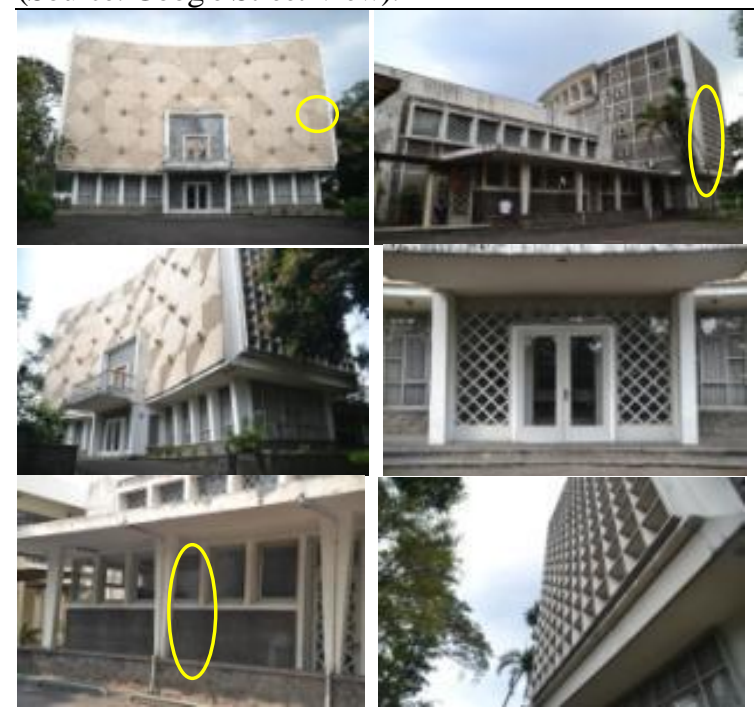

Figure 9. Balai Pertemuan Ilmiah ITB, 2013 (Source: UNIKOM Architecture student survey).
Bended cubical Built in late 1940's, it • historical value: (+) form; variety vent was first functioned as contains local holes; oblique Faculty of Science of pillars; concrete ITB. Later on, it frame functioned as history, notably for Institute of Technology scientific meeting hall Bandung as their up to present. It takes form in cubism (international) style but with specific ornamentation of first Science Faculty, though its value in city scale needs further research.

Jengki, notably found $\bullet$ architectural value: on pillars and vent holes. It seems that (+) a great example of modern the architecture is an experiment of modern architecture, a rather eclectic style, a mixture of architecture development in Bandung that contain Jengki characteristic and international style and Jengki. also the international style form.

- scientific value: (+) an object of study on architectural development in Bandung.

- social and cultural value: (?)

- Age: (+) age reached 50 years. 


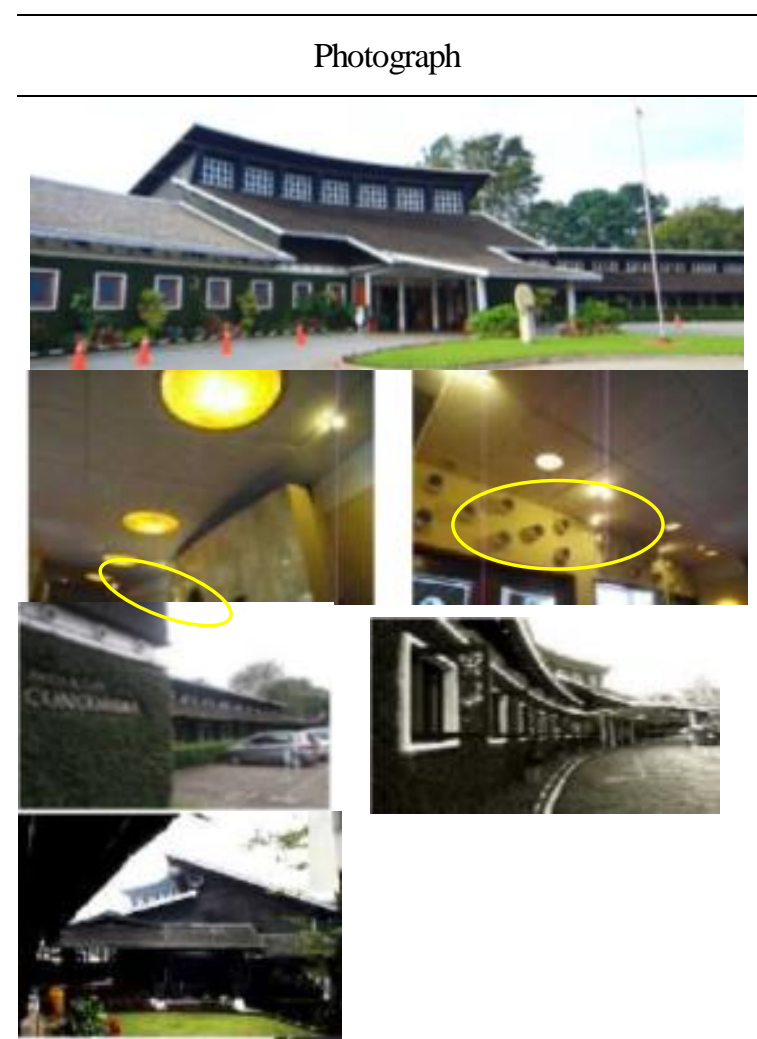

Figure 10. Concordia Hotel (Balai Pertemuan Bumi Sangkuriang), 2013 (Source: UNIKOM Architecture student survey).
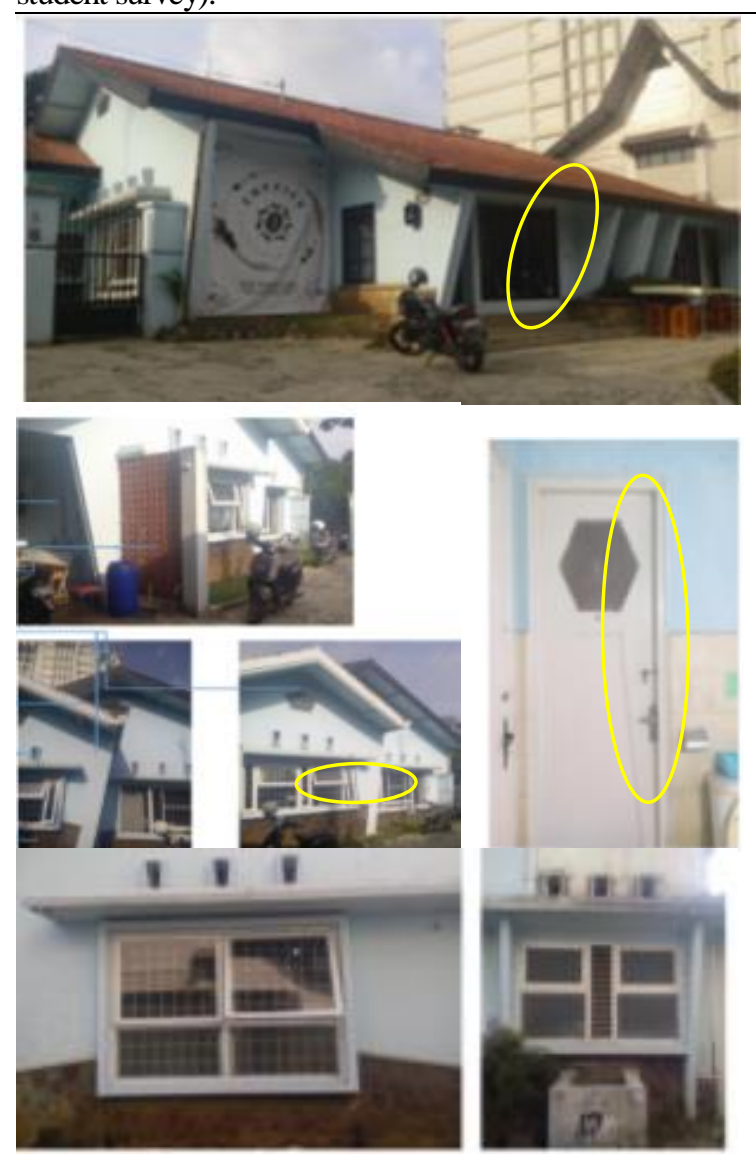

Figure 11. Cofindo Coffee Shop, 2013 (Source: UNIKOM Architecture student survey).

\begin{tabular}{|c|c|c|}
\hline $\begin{array}{l}\text { Exterior Physical } \\
\text { Characteristics }\end{array}$ & $\begin{array}{c}\text { Social-cultural- } \\
\text { historical information }\end{array}$ & $\begin{array}{l}\text { Assessment on } \\
\text { heritage criteria }\end{array}$ \\
\hline $\begin{array}{l}\text { Bended cubical } \\
\text { form; variety vent } \\
\text { holes; concrete } \\
\text { frame }\end{array}$ & $\begin{array}{l}\text { Built in } 1957 \text { by N. V. } \\
\text { De Concurent, } \\
\text { designed by Ir. A. W. } \\
\text { Gmeilig Meylin (a } \\
\text { Dutch architect), as } \\
\text { substitute to Societeit } \\
\text { Concordia located in } \\
\text { the city center } \\
\text { because the later } \\
\text { building was used for } \\
\text { Asian-African } \\
\text { Conference in } 1955 \text {. It } \\
\text { was meant as new } \\
\text { Societeit Concordia } \\
\text { on demand of the } \\
\text { government. The } \\
\text { building is now } \\
\text { functioned as hotel. } \\
\text { The overall building } \\
\text { was built in late } \\
\text { modern tropical style } \\
\text { while the } \\
\text { characteristic of } \\
\text { Jengki is only found } \\
\text { on vent holes. }\end{array}$ & $\begin{array}{l}\text { - historical value: (+) } \\
\text { It has relation with } \\
\text { Asian-African } \\
\text { Museum building. } \\
\text { A political substitute } \\
\text { of a Dutch social } \\
\text { club, the Societeit } \\
\text { Concordia. } \\
\text { - architectural value: } \\
\text { (+) an example of } \\
\text { modern tropical } \\
\text { style with Jengki } \\
\text { element on it. } \\
\text { - scientific value: (+) } \\
\text { an object for } \\
\text { architectural and } \\
\text { interior example } \\
\text { from the era. } \\
\text { - social and cultural } \\
\text { value: (+) link with } \\
\text { AA Museum to } \\
\text { replace its colonial } \\
\text { function elsewhere. } \\
\text { - Age: (+) age } \\
\text { reached } 50 \text { years. }\end{array}$ \\
\hline
\end{tabular}

Oblique pillars as A private house extension of wall; reused as a café and pentagon wall on coffee shop. It shows the side façade; quite strong Jengki trapezium characteristics on its opening; variaties elements. vent holes; stone No historical covering; information obtained geometric for instance. ornament on door; concrete frame

- historical value: (?)

- architectural value: (+) an example of Jengki architecture and its element.

- scientific value: (?)

- social and cultural value: (?)

- Age: (+) age reaching 50 years. 


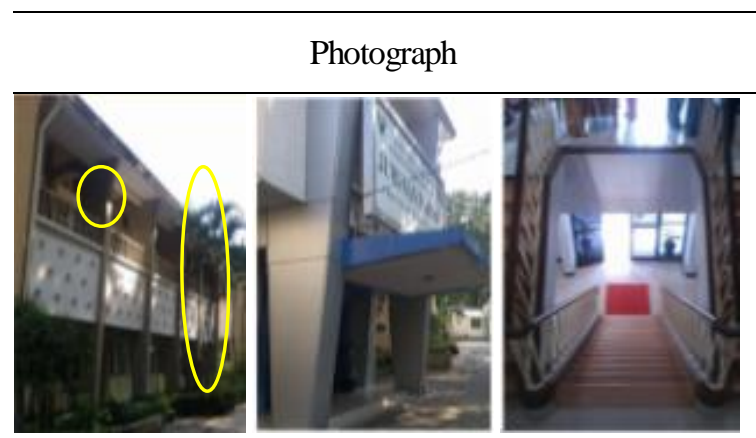

Figure 12. POLTEKES, 2013 (Source: UNIKOM

Architecture student survey).

$\begin{array}{lll}\begin{array}{c}\text { Exterior Physical } \\ \text { Characteristics }\end{array} & \begin{array}{c}\text { Social-cultural- } \\ \text { historical information }\end{array} & \begin{array}{c}\text { Assessment on } \\ \text { heritage criteria }\end{array} \\ \text { Varieties vent } & \text { The building was first } & \bullet \text { historical value: + } \\ \text { holes; oblique } & \text { used as student } & \bullet \text { architectural value: + } \\ \text { pillars; flat roof } & \text { housing for nursing } & \bullet \text { scientific value: ? } \\ \text { on terrace. } & \text { students. Later it is } & \bullet \text { social and cultural } \\ & \text { reused as state } & \text { value: + } \\ & \text { pharmacy } & \bullet \text { Age: + } \\ & \text { polytechnic. It } & \\ & \text { experienced 5 } & \\ & \text { renovations without } & \\ & \text { major physical } & \\ & \text { changes. The last } & \\ & \text { renovation was façade } & \\ & \text { renewal by adding } & \\ & \text { aluminum panel } & \\ & \text { covering as seen on } & \\ & \text { the pillar and terrace } & \\ & \text { roof. The interior } & \\ & \text { structure } \\ & \text { (architectural } \\ & \text { element) is still quite } & \\ \text { intactt. } & \\ & \end{array}$

The same physical characteristic apply to Balai Pertemuan Ilmiah ITB that expresses strong cubical modern form, though it has bended façade and decorated with Jengki decorations (oblique pillars, concrete variety vent holes). Locally, this building has a history for ITB as the first Science Faculty. It shows also an important architectural development in Bandung. Therefore, it contains architectural value and fullfill the age criteria of heritage object. However, its significance needs to be explored further.

The Bumi Sangkuriang, suggested to be Jengki as well by Khalil, shows characteristic of modern tropical architecture. It has no oblique pillars, no asymmetric window, no pentagon form, only variety vent holes as traits of Jengki. The overall look of the building resembles a little to famous ITB West Wing Hall with dominant use of natural material. Regarding the Dutch architect, Meylin, it is quite doubtful that Bumi Sangkuriang is of pure Jengki. This building has historical and social significances where it was built with an intent to move Societeit Concordia from the city center to the presented new building. One of the reason of this displacement was that the Societeit Concordia building in the city center (now Museum Asia Afrika) was to be used for Asia and Africa Conference in 1955.

Other examples: Poltekkes, Alpha Omega Church, and several examples of private houses show variant of Jengki traits around Bandung. They propose different Jengki traits that suggest their different development, probably according to year of construction. The Alpha Omega Church and a house in Sampurna street has bended end wall that meet the roof. This trait isn't found elsewhere in the example of earlier development. House in Sampurna also has different kind of window very differ from other house example in Abdurrahman Saleh who has trapezium window and rhomb vent holes.

Considering search and evaluation on significances of each building, housing examples retain (+) value from 1 to 3 . Meanwhile, the public buildings retain (+) value between 2 to 5 . In this case, mostly public building can be recognized as heritage object. Bandung local legislation No. 19/2009 acknowledges any building of 50 years old to be categorized as heritage. Further, significances need to be fulfilled to input a building in a heritage list. By interpretation, any building that has reach 50 years and possess one other criteria of significance, for example architectural significance (of a specific era, unique and not to be found in other place, etc) can be listed as heritage.

In this regard, based on Tabel 1, building with at least two (+) values could be considered heritage object in a condition that it is classified as Class C heritage (according to Bandung local legislation No. 19/2009). In this case of Jengki, the two significances are age and architectural significance. In order to have stronger legitimation in heritage building listing, other significances needs to be researched further.

However, Jengki typology marked an important architectural development in Indonesia. Seen from 
architectural movement timeline, in the 19th century, Indische Empire Style was developed in Indonesia. On the transition of the 19th to 20th century, an architectural style named by scholars as Transitional style, was developped. By the 20th century, especially in big cities, architecture was developed in modern style inspired by the international modern movement. The jengki is other development different from the previous style. It serves a part in architectural timeline in Indonesian modern architectural movement. In this regard, the Jengki style has a scientific role in architectural history, besides its aesthetic value. Further research on significances needs to be done to individual buildings as object to evaluate each one's eligibility in heritage list.

\section{CONCLUSION}

From the elaborated data on the table, we can see that to identify a building to be part of the Jengki style is not simple. Regarding only the physical element is not enough. The examples of Jengki in Bandung, some are more modern cubical international style with Jengki variety on its façade, or modern tropical with Jengki variety on its façade. It suggests that Jengki in Bandung needs more exploration on variety of the style, whether it came from later development of Jengki or just variant differs from those found in Jakarta, Semarang and Malang.

More in-depth research and documentation are needed to elaborate deeper this traits to recognize Jengki development in Bandung because it is different from other city that have been studied so far. Historical record on each building is important as basic data.

As the Bandung local legislation No. 19/2009, recognized age as a category to assess an object as heritage, some Jengki built up to 1965 can therefore be considered heritage object under one condition that it fulfill at least two significances, of which one is in the following: historical, architectural, scientific, social cultural. In preliminary premis, the Jengki architecture has age, architectural and scientific significances. However, in depth research and documentation on each individual Jengki in Bandung is necessary to strengthen its legitimation as heritage object.

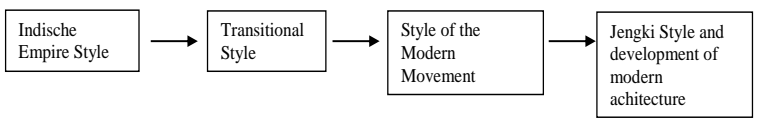

\section{ACKNOWLEDGMENT}

I would like to thank you Ms. Frances Affandy and Tariq Khalil who have introduced me to Jengki. I would like also express my gratitude Mr. Totok Roesmanto whom I contacted once in 2011 concerning Jengki research and encourage me to explore it more.

\section{REFERENCES}

Handinoto \& Hartono, S. (2006). Arsitektur Transisi di Nusantara Dari Akhir Abad 19 ke Awal Abad 20 (Studi Kasus Komplek Bangunan Militer di Jawa pada Peralihan Abad 19 ke 20). DIMENSI, 34(2), pp.81-92.

Kurniawan, K. R. (1999). Identifikasi Tipologi dan Bentuk Arsitektur Jengki di Indonesia Melalui Kajian Sejarah. Laporan Penelitian Jurusan Arsitektur FT - UI.

Mariana, Y. (2013). Tipologi Bangunan Di Jalan Pakubowono Kebayoran Baru, Jakarta Selatan. ComTech, 4(1), pp.33-42.

Nugroho, T., Ningsih, E.D. \& Tiara, D.. (2013). Analisis Arsitektur Jengki Di Kota Bandung. Fakultas Teknik \& Ilmu Komputer Jurusan Teknik Arsitektur Universitas Komputer Indonesia.

Nurfindarti, E. \& Zulkaidi, D. (2015). Strategi Pengelolaan Cagar Budaya Kota Bandung. Jurnal Perencanaan Wilayah Dan Kota B Sappk, 4(1), pp.83-103.

Prijotomo, J. (1996). When West Meets East: One Century of Architecture in Indonesia (1890s1990s). Architronic.

R. Fattah, Abdul, R., Hutami, P.S., Glorianto, S., Ekselsdo \& Ramadhan P. Giri. (2013). Laporan Analisa Tipologi Bangunan Jengki Mata Kuliah: Tipologi Arsitektur Studi Kasus: Gedung Farmasi Poltekes Kemenkes Bandung Jalan Prof. Eyckman Nomor 24 Bandung. Fakultas Teknik \& Ilmu Komputer Jurusan Teknik Arsitektur Universitas Komputer Indonesia.

Rikhardi, A., Juliansyah, R., Sandi, A. K. \& Kusuma, A. A. (2013). Analisis Arsitektur Jengki: Makalah. Fakultas Teknik \& Ilmu Komputer Jurusan Teknik Arsitektur Universitas Komputer Indonesia.

Setyabudi, I., Antariksa \& Nugroho A.M. (2011). Transisi Ruang Arsitektur Rumah Jengki di Kota Malang, Singosari dan Lawang. Universitas Brawijaya Program Magister Dan Doktoral Program Studi Arsitektur Lingkungan Binaan.

Setyabudi, I., Antariksa \& Nugroho A.M. (2011). Makna Lokal Rumah Tinggal Bergaya Jengki Di Kota Malang. Proceeding - National Seminar: The Local Tripod. http://eprints.unsri.ac.id/ 
3675/1/UB_Local_Tripod_26_Maret_2011.com pressed.pdf.

Setyabudi, I., Antariksa \& Nugroho A.M. (2011). Tipo-Morfologi Arsitektur Rumah Jengki di Kota Malang dan Lawang. Universitas Brawijaya Program Magister Dan Doktoral Program Studi Arsitektur Lingkungan Binaan.

Suprayitno (2015). Arsitektur Jengki Salah Satu Warisan Sejarah Arsitektur Indonesia Di Kota Medan. Arbitek, 1(1).

Susilo, G.A. (2009). Arsitektur Jengki: Bergeometri Yang Kreatif. Spectra, 13(VII), pp.15-23.
Tresna, K. M., Giovana, C., Cahyana, A.S. \& Almuchtar, M. N. (2013). Laporan Analisa Tipologi Bangunan Jengki Objek Terpilih: Gedung Balai Pertemuan Ilmiah ITB. Fakultas Teknik \& Ilmu Komputer Jurusan Teknik Arsitektur Universitas Komputer Indonesia.

Widayat, R. (2006). Spirit Dari Rumah Gaya Jengki Ulasan Tentang Bentuk, Estetika, Dan Makna. DIMENSI INTERIOR, 4(2), pp. 80-89.

Zainal, N., Permana, A., Mardian, A. \& Abdulrahman, I. (2013). Paper Hotel Concordia. Fakultas Teknik \& Ilmu Komputer Jurusan Teknik Arsitektur Universitas Komputer Indonesia. 